\title{
Impacts of climate change on coastal benthic ecosystems: assessing the current risk of mortality outbreaks associated with thermal stress in NW Mediterranean coastal areas
}

\author{
Ivane Lilian Pairaud ${ }^{1,{ }^{*},}$ Nathaniel Bensoussan ${ }^{2}$, Pierre Garreau ${ }^{3}$, Vincent Faure ${ }^{2}$, \\ Joaquim Garrabou ${ }^{4,5}$
}

\author{
1 Ifremer, LER PAC, F-83507, La Seyne sur Mer, France \\ 2 IPSO FACTO, SCOPARL, Oceanography Department, Marseille, France \\ 3 Ifremer, DYNECO PHYSED, F-29280, Plouzane, France \\ ${ }^{4}$ Institut de Ciencies de la Mar (ICM-CSIC), Barcelona, Spain \\ ${ }^{5}$ UM 110, CNRS/INSU, IRD, Aix-Marseille Université, Université du Sud Toulon Var, Mediterranean Institute of \\ Oceanography (MIO), Marseille, France
}

*: Corresponding author : Ivane Lilian Pairaud, email address : ivane.pairaud@ifremer.fr

\begin{abstract}
:
In the framework of climate change, the increase in ocean heat wave frequency is expected to impact marine life. Large-scale positive temperature anomalies already occurred in the northwestern Mediterranean Sea in 1999, 2003 and 2006. These anomalies were associated with mass mortality events of macrobenthic species in coastal areas (0-40 m in depth). The anomalies were particularly severe in 1999 and 2003 when thousands of kilometres of coasts and about 30 species were affected. The aim of this study was to develop a methodology to assess the current risk of mass mortality associated with temperature increase along NW Mediterranean continental coasts. A 3D regional ocean model was used to obtain the temperature conditions for the period 2001-2010, for which the model outputs were validated by comparing them with in situ observations in affected areas. The model was globally satisfactory, although extremes were underestimated and required correction. Combined with information on the thermo-tolerance of a key species (the red gorgonian $P$. clavata) as well as its spatial distribution, the modelled temperature conditions were then used to assess the risk of mass mortality associated with thermal stress for the first time. Most of the known areas of observed mass mortality were found using the model, although the degree of risk in certain areas was underestimated. Using climatic IPCC scenarios, the methodology could be applied to explore the impacts of expected climate change in the NW Mediterranean. This is a key issue for the development of sound management and conservation plans to protect Mediterranean marine biodiversity in the face of climate change.
\end{abstract}

Keywords: Climate change ; Benthic communities ; Ocean modelling ; Model validation ; Impact mapping 


\section{Introduction}

Recent climatic trends have resulted in significant changes in marine ecosystems, such as pelagic productivity, geographical distribution of species, community composition and migratory patterns (Perry et al. 2005, Wernberg et al. 2011, Coll et al. 2010). The increase in diseases and mass mortality outbreaks in tropical and temperate coastal ecosystems during the past few decades has also been linked to modifications in environmental conditions caused by global change (Harvell et al. 1999, Harley et al. 2006, Doney et al. 2012). These events have occurred in the context of significant warming of the global average surface temperatures $\left(+0.76{ }^{\circ} \mathrm{C}\right.$ for the 20th century; IPCC 2007$)$ and upper global ocean temperatures $\left(+0.3{ }^{\circ} \mathrm{C}\right.$ from 1950 to 2000; Levitus et al. 2000). This warming trend was associated with an increase in extreme climatic events worldwide (Trenberth 2012). Whereas the shifts in species distribution were associated with gradual warming, mortality outbreaks were usually associated with extreme temperature anomalies (Garrabou et al. 2009, Wernberg et al. 2013).

In recent decades a clear warming trend has been observed in the north-western Mediterranean Sea (Bensoussan et al. 2009, Calvo et al. 2011). In the last two decades, mass mortality events of benthic species have been reported, and in most cases these events were concomitant with large scale positive summer anomalies (Pérez et al. 2000, Cerrano et al. 2000, Garrabou et al. 2009, Bensoussan et al. 2010, Crisci et al. 2011). These mortality events were particularly severe in 1999 and 2003 as they occurred at large spatial scales $(>1000 \mathrm{~km})$ and affected up to 30 species belonging to five different phyla (Cerrano et al. 2000, Pérez et al. 2000, Garrabou et al. 2009) to a depth of $50 \mathrm{~m}$ along the coasts of Spain, France and Italy. Although the affected communities may be living under the seasonal thermocline level (i.e. in “cold” water), intermittent and transitory processes (upwellings, downwellings, vertical mixing, horizontal advection, heat waves) can nevertheless affect these habitats (Russell et al. 2012).

The actual climate projections in the Mediterranean area for the 21st century predict an increase in warming $\left(+1.8\right.$ or $+3.5^{\circ} \mathrm{C}$ depending on the emission scenario; IPCC 2007) and changes in wind regimes. Inter-annual climate variability is predicted to generally increase, as is the frequency of extreme heat and drought events and the length of summer conditions (Déqué et al. 2007, Giorgi et al. 2008). As a response to these changes, the surface temperature of the NW Mediterranean Sea may undergo an average warming of $2{ }^{\circ} \mathrm{C}$ to $4{ }^{\circ} \mathrm{C}$ by the end of this century (Somot et al., 2006 and 2008), along with an increase in the frequency and magnitude of extreme events.

Under these conditions, the incidence and virulence of mortality events may spread over larger geographic areas and affect a wider spectrum of organisms. This scenario combined with additional impacts (e.g. fishing, habitat destruction and invasive species) could cause a marine biodiversity loss crisis in the Mediterranean Sea (Coll et al. 2010). Analyzing the impact of these events at appropriate spatial and temporal scales and biological organization levels (species, populations, communities) is crucial to accurately predict future changes in marine ecosystems and propose appropriate management and conservation plans.

In this context, the main aim of our work is to provide tools to investigate the potential impacts of climate change on marine benthic biodiversity. We plan to identify the warming conditions expected by the end of the $21^{\text {st }}$ century by combining climate scenarios with high resolution ocean models, which will be linked with the biological responses to temperature changes.

In this paper, we present a methodological approach for the assessment of the current risk of 
mass mortality from severe seawater warming in NW Mediterranean coastal areas. First, the NW Mediterranean configuration of the 3D coastal ocean model MARS3D (Lazure and Dumas 2008) was used to reproduce summer conditions observed during the last ten years. Second, the comparison of model temperature hindcasts with available in situ temperature time series allowed us to assess the model's ability to reproduce the summer warming conditions. Then, the temperature hindcasts were combined with information on the response of a model species to temperature conditions to determine the level of mortality risk in the areas and depth ranges where the model species develops. As a result we could build maps of current mortality risks in coastal benthic ecosystems. In this study we chose as model species the red gorgonian Paramuricea clavata. This species is considered a key species in the Mediterranean coralligenous communities and determines, with its arborescent colonies (up to $1 \mathrm{~m}$ in height), the community structure (biomass and biodiversity). The results provide the basis for validation of the approach to explore the expected mortality risks under the climate change scenario.

\section{Materials and Methods}

\subsection{Description of the 3D coastal ocean model}

The 3D numerical ocean model MARS3D (Model for Application at Regional Scale; Lazure and Dumas 2008) was used to simulate temperature variations in the NW Mediterranean coastal areas over the period 2001-2010. It is a free surface primitive equation model under Boussinesq and hydrostatic assumptions, with an Arakawa-C grid.

The model configuration used for this study was the NORMED (for NORth west MEDiterranean) configuration of MARS3D which covers the region between 39 $30^{\prime} \mathrm{N}$ and $44^{\circ} 30^{\prime} \mathrm{N}$ in the western basin. It was designed to reproduce mesoscale variability, with a horizontal resolution of $1.2 \mathrm{~km}$ and 30 sigma-coordinate vertical levels. The initial and open boundary conditions were provided by a global ocean model in the framework of the Mediterranean Operational Oceanography Network (http://www.moon-oceanforecasting.eu). The results were exploited after a 5-month spin-up. The atmospheric forcing for 2005-2010 was derived from the non-hydrostatic MM5 model (Mesoscale Model 5; Grell et al. 1994) developed by the National Center for Atmospheric Research (3 to $9 \mathrm{~km}$ horizontal resolution). Between 2001 and 2004, the results of the French Met-Office model ALADIN (10 km resolution) were used as an alternative. For the years 2001 to 2008, we used the 3-hourly NORMED outputs from a previous work on small-scale pelagic recruitment (Nicolle et al. 2009).

Similar configurations of MARS3D in the NW Mediterranean Sea have already been performed and evaluated for operational purposes (PREVIMER; http://www.previmer.org/en) or used to investigate surface ocean circulation (Andre et al. 2005; Andre et al. 2009), associated cross-shelf exchanges (Rubio et al. 2009), sediment dynamics (Dufois et al. 2008) or the effect of high resolution atmospheric forcing on the dynamics (Schaeffer et al. 2011).

A previous work dealing with the validation of a coastal model of the eastern Gulf of Lions for the years 2007-2008 (Pairaud et al. 2011) showed that the NORMED model satisfactorily reproduces the alternating increase and decrease in temperature at the Riou site (Figure 1), corresponding to cooling due to upwelling events alternating with warming due to atmospheric forcing and the arrival of warmer surface waters on the shelf from the south. Even if extremes were underestimated, the spatial extent and duration of summer upwelling events were well reproduced in comparison with satellite SST imagery. 


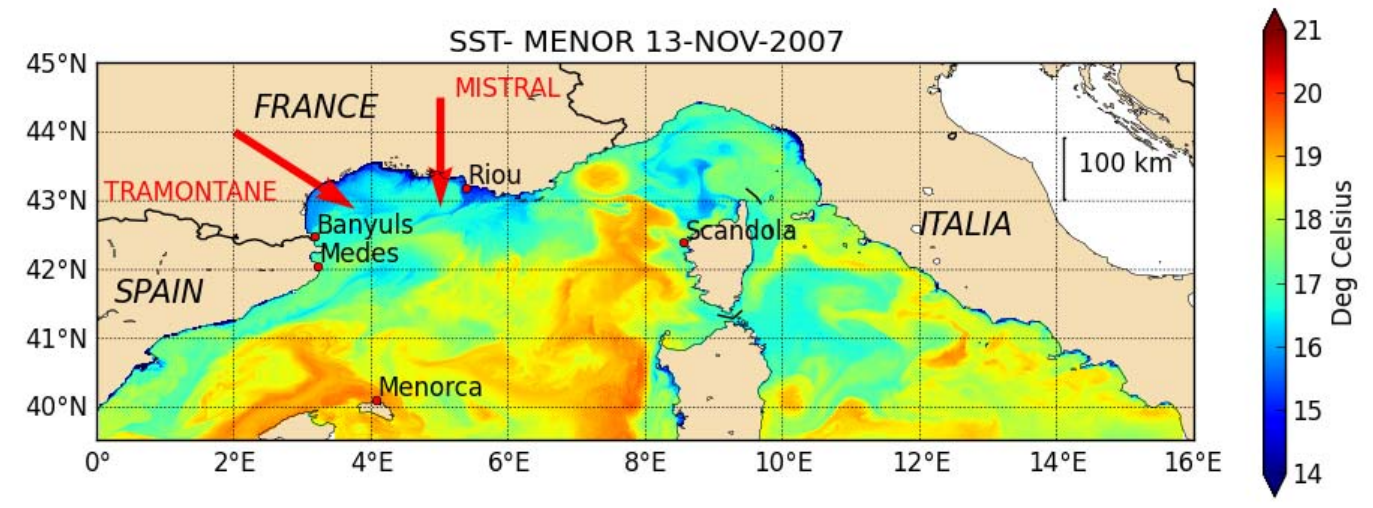

\section{Figure 1}

Study area: domain of the NORMED (MARS3D) high resolution hydrodynamical model and TMedNet sites used for qualification of coastal simulations: Riou, Banyuls, Medes, Menorca and Scandola. The North (Mistral) and North-West (Tramontane) wind directions are shown.

\subsection{Model validation for summer temperature conditions}

In situ temperature time series (see below) were used to assess the NORMED model's ability to reproduce summer temperature conditions and their seasonal to inter-annual variations. A statistical analysis, coupling the usual bias, RMS, correlation and percentile computation was performed. To this end, the modelled temperature was interpolated at the depth of recorded temperatures. Both datasets were averaged daily to facilitate the comparison, considering data recorded at 3-hourly intervals for NORMED and at 1-hourly intervals for T-MedNet time series. These high resolution series of observed temperature data have been already used to analyze the relationships between summer conditions and the degree of impacts during mass mortality events in different parts of the NW Mediterranean (Pérez et al. 2000, Bensoussan et al. 2010, Cebrian et al. 2011, Crisci et al. 2011). In our study, the focus was on the stratified period from May to October when abnormal warming events were reported.

The T-MedNet network (www.t-mednet.org) is composed of long term high resolution temperature series of the Mediterranean coastal waters (0-40 m). From the network, we chose five sites that are representative of different hydrodynamic forcing and different temperature trends and variability including the Balearic Islands (Menorca), Catalan Coast (Medes), Gulf of Lions (Banyuls), Provence area (Riou) and west Corsica (Scandola) (Figure 1 and Table 1). The temperature series were recorded in situ by Stowaway Tidbits, Stowaway Tidbits v2 and HOBO Water Temp Pro v2 autonomous sensors and recovered once or twice a year by divers, usually before and after the summer period. The temperature sensors were set to collect hourly records with a precision of $0.2^{\circ} \mathrm{C}$, and a resolution of $0.15{ }^{\circ} \mathrm{C}$ to $0.02{ }^{\circ} \mathrm{C}$. In general, the sensors were placed at $5 \mathrm{~m}$ intervals from a depth of 5 to $40 \mathrm{~m}$ at each study site. The data loggers were attached to plastic screws sealed along rocky walls. 


\begin{tabular}{|c|c|c|c|}
\hline Site & Latitude, Longitude & Depths( m) & Starting dates \\
\hline Medes (N. Spain) & $42.050 \mathrm{~N}, 3.227 \mathrm{E}$ & $\begin{array}{l}10 ; 25 ; 35 \\
10-40 ;(5)\end{array}$ & $\begin{array}{l}\text { July } 2002 \\
\text { July } 2004 \text { (November 2004) }\end{array}$ \\
\hline Riou (Marseilles, France) & 43.174 N,5.392 E & $\begin{array}{c}10 ; 25 ;(40) \\
10-40 ;(5)\end{array}$ & $\begin{array}{l}\text { June } 1999 \text { (June 2000) } \\
\text { June } 2003 \text { (July 2004) }\end{array}$ \\
\hline Scandola (Galeria, Corsica) & $42.382 \mathrm{~N}, 8.547 \mathrm{E}$ & $10-40 ;(5)$ & May 2004 (March 2005) \\
\hline Banyuls (W. Gulf of Lions, France) & 42.470 N,3.172 E & $5-40$ & March 2006 \\
\hline Menorca (Spain) & $40.100 \mathrm{~N}, 4.080 \mathrm{E}$ & $5-35$ & July 2004 \\
\hline
\end{tabular}

\section{Table 1}

Location of temperature sensors, depths, and start dates. Discrete depths are separated by semicolons. Within the depth ranges, measurements were made every $5 \mathrm{~m}$. Start dates between brackets correspond to the depths between brackets. Series were examined until end of year 2010.

\subsection{Assessing the biological response to thermal stress at sub-regional scale (NW Mediterranean)}

The assessment of the biological response required (1) to define the response of the populations to different temperature conditions and (2) to know the geographic distribution of the species. In this study, we used the data available for the red gorgonian Paramuricea clavata, because the dataset for this species was the largest available, thus allowing a reliable evaluation of response to warming. In addition $P$. clavata was one of the most affected species during the mass mortality events affecting the coralligenous community.

\subsubsection{Definition of thermo-tolerance functions}

The themo-tolerance functions related how the length of exposure (number of days) to different temperatures (from $23{ }^{\circ} \mathrm{C}$ to $28{ }^{\circ} \mathrm{C}$ ) affected the populations (e.g. the period of exposure to different temperatures required to observe signs of tissue necrosis). Two main datasets were combined to build the thermo-tolerance functions. Firstly, using data from field surveys on the impact of increasing temperatures on populations for the last decade in different areas of the NW Mediterranean, we estimated the impacts as the percentage of affected colonies within populations. A colony was considered as affected when it displayed more than $10 \%$ of denuded axis (see Garrabou et al. 2009 for more details). These data were linked to temperature conditions obtained in the same areas (Bensoussan et al. 2010, Crisci et al. 2011, see Section 2.2) to determine the duration and level of thermal stress concomitant with population necrosis observed in the field. The number of days above different temperature thresholds $\left(24,25,26,27\right.$ and $28^{\circ} \mathrm{C}$ ) observed during the mortality events were used in the thermo-tolerance functions.

Secondly, we reviewed available data from thermo-tolerance experiments concerning the red gorgonian Paramuricea clavata conducted in aquariums. In these experiments populations were subjected to different temperature treatments ranging from $23{ }^{\circ} \mathrm{C}$ to $28{ }^{\circ} \mathrm{C}$ for different periods ranging from four days to more than 80 days (Bally and Garrabou 2007, Coma et al. 2009, Previati et al. 2010, Crisci et al. 2011, Crisci 2011, Kipson 2013). The experiments concerned populations from different areas across the NW Mediterranean (Spain, France and 
Italy). To build the thermo-tolerance function, for each temperature level, we searched for the first day when populations displayed the first signs of necrosis (e.g. the colour of the tissue had changed from red-yellow to greyish and/or blackish and the affected tissues had started to detach).

The criteria for the definition of the thermo-tolerance function is provided in Section 2.4 (point 2) and the corresponding thermo-tolerance function is presented in Section 3.2.

\subsubsection{Determining the distribution of Paramuricea clavata in the NW Mediterranean}

The presence as well as the upper distribution limit of $P$. clavata populations in sectors (30-60 $\mathrm{km}$ of coastline) of the NW Mediterranean was assessed by a review of the literature, interviews with Marine Protected Areas managers and research teams, as well as data from citizen science initiatives (www.observadoresdelmar.es, http://www.progettomac.it/Paramuricea_clavata.asp). For the survey, the coastline was first divided in 14 "coherent" sub-regions of 50 to $150 \mathrm{~km}$ width delimited by main geomorphological traits, expert knowledge and also Spain-France-Italy state frontiers. Each sub-region was then divided in two to three sub areas. Presence and upper distribution limit (UDL, in meters) data concerning gorgonian species were pooled inside these sub-areas. For each sub-area, the UDL was calculated as the average of observations or integrative expert knowledge.

\subsection{Maps of the risk of mass mortality}

To build maps of the risk of mass mortality associated with thermal stress for Paramuricea clavata populations, temperature conditions modelled for different NW Mediterranean areas were combined with the geographic distribution information and the thermo-tolerance functions of the species. The work consisted of four steps:

1- NORMED temperatures were extracted along the coastline within the $60 \mathrm{~m}$ isobath for the years 2001-2010, on the continental shelf from Spain to Italy (Figure 2). Corrections were applied to the simulated temperatures using the bias computed by comparison with observations, as a function of the area concerned (see results section).

2- For each year, we calculated the number of days when the temperature hindcast was above $23{ }^{\circ} \mathrm{C}$ to $28{ }^{\circ} \mathrm{C}$. This data was crossed with the thermo-tolerance response function to evaluate the risk of mortality for each area and each depth range considered. The temperature stress was classified in four lethal risk levels: sub-lethal, moderate, high, and extreme. The last three were defined as the minimum, mean and maximum number of days of exposure at each temperature to when the first signs of necrosis were observed. The sub-lethal level was defined as half the duration of exposure of the high lethal level (or, if less, equal to the duration of the moderate lethal level). The maximum stress level over the 10 year period was calculated and used for the assessment of the current mortality risk.

3- The temperature stress level was crossed with information on the geographic and depth distribution of the target species to identify exposed populations/areas.

4- From the obtained information, two types of maps were drawn for Paramuricea clavata populations for the period 2001-2010: (a) maps of potential temperature stress level at chosen depths, and (b) a map of impact by taking the mortality risk level attributed at the depth of the upper distribution limit of the populations for each geographical area. The latter map allowed us to compare the degree of impact among regions along the coastline. 


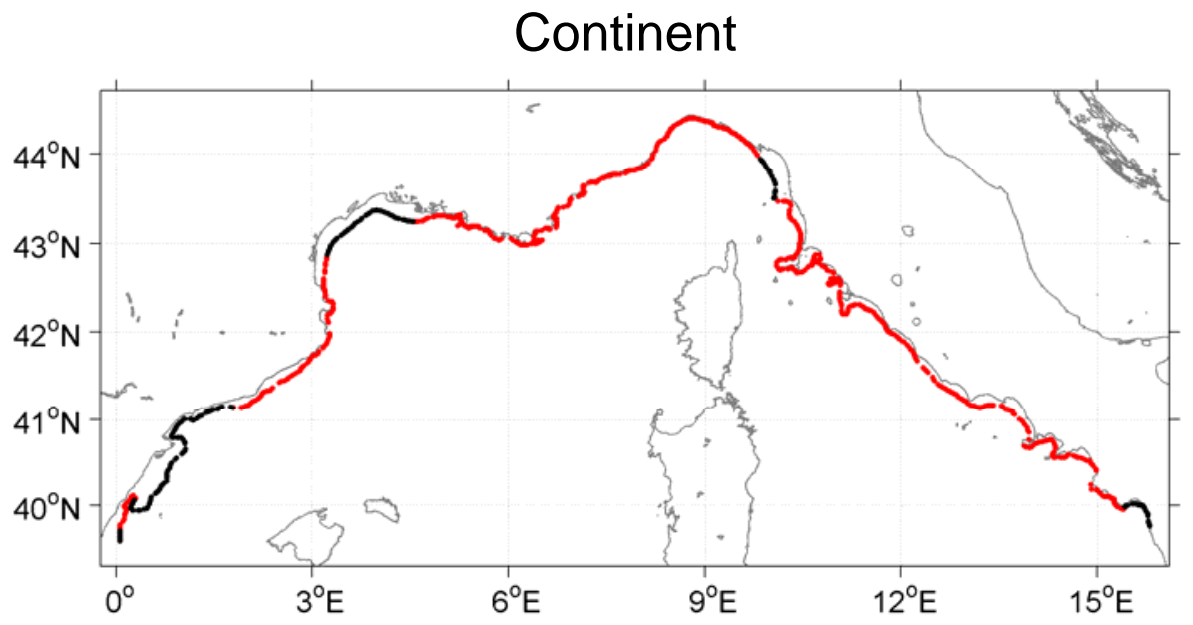

Figure 2

Example of coastal band used for extraction of NORMED temperature hindcasts defined by the $60 \mathrm{~m}$ isobath for the continental coastline. The distribution of Paramuricea clavata along the coastline is in red.

\section{Results and discussion}

\subsection{Warming events and temperature conditions in the early $21^{\text {st }}$ century in the NW Mediterranean from in situ temperature time series and modelling}

\subsubsection{Observed warming events}

A previous study by Bensoussan et al. (2010) focused on four contrasting sites in the NW Mediterranean T-MedNet network including Medes, Riou and Scandola over the period 19992006. During winter, the observed temperature was nearly constant $\left(11^{\circ} \mathrm{C}-13^{\circ} \mathrm{C}\right)$ due to wind induced mixing and negative net heat fluxes. Near the coast, local colder events caused by extreme meteorological forcing were identified under strong Mistral or Tramontane gusts and cold dry air conditions. From late spring until early autumn, a seasonal thermocline occurred at a depth of 20-30 m. In summer, the dominant winds in the area strongly impacted the temperature pattern. The Mistral (northerly) and Tramontane (northwesterly) (Figure 1), blew regularly for a few days and caused intermittent upwelling (Riou) /downwelling (Banyuls/Medes) dynamics in the Gulf of Lions (Millot, 1979 and 1990; Pairaud et al. 2011). They also impacted the Scandola site when the gust reached the island of Corsica. Summer temperatures were $22{ }^{\circ} \mathrm{C}-24{ }^{\circ} \mathrm{C}$ near the surface and $18{ }^{\circ} \mathrm{C}-20{ }^{\circ} \mathrm{C}$ at depth, with distinct hydrographical conditions at each site despite their similar annual temperature cycles. Riou was the coldest and the most vertically variable site within the water column. Scandola was the warmest site in its subsurface waters because of the stable summer stratification conditions which favoured heating through air-sea exchanges, and also displayed maximum variability at a depth of 25-30 m because of oscillations of the thermocline (Bensoussan et al. 2010). Medes showed intermediate conditions and the highest variability at a depth of $40 \mathrm{~m}$ due to recurring downwelling (Bensoussan et al. 2010). The inter-annual variability at all 
stations revealed abnormal warming events of differing magnitude in 1999, 2003 and 2006 (Figures 3 and 4 in Bensoussan et al. 2010), which were emphasised when considering longer multi-decadal temperature time series at l'Estartit and Villefranche. At a depth of $10 \mathrm{~m}$ for example, the highest summer mean temperature was measured at Riou in 1999 and at Medes in 2003.

In the present study, Menorca and Banyuls sites were included as they showed different behaviour, and all sites were analysed over the period 2001-2010. Temperatures from a depth of 5 to $40 \mathrm{~m}$ were compared at each site between May and October for selected years between 2005 and 2009 (Figure 3). The average summer (July to September) temperature for the period 2001 to 2010 never exceeded $21{ }^{\circ} \mathrm{C}-22{ }^{\circ} \mathrm{C}$ at a depth of $10 \mathrm{~m}$ at Riou, Medes and Banyuls, whereas it reached $24.5{ }^{\circ} \mathrm{C}$ at Scandola and $26{ }^{\circ} \mathrm{C}$ at Menorca. The mean summer temperature at Banyuls was the coldest as this site is located in an almost permanently windy area, close to Medes but colder under favourable upwelling conditions (rare southerly wind). Menorca was the warmest site in depth as its temperature reached more than $25^{\circ} \mathrm{C}$ in the top $25 \mathrm{~m}$ of the water column on several days in summer (Figure 3).

When we focused on the strong warming events in summer 2006 and 2009, the different locations were seen to be affected differently. In 2006, the main summer feature was the absence of Mistral and Tramontane winds in July, leading to a positive temperature anomaly in the Gulf of Lions, Catalan and Corsica waters. The average temperature at Scandola was not very different from other years (Figure 3), but the graph showed a short intense warming event in July 2006, with temperatures above $27^{\circ} \mathrm{C}$ in the first $10 \mathrm{~m}$ of the water column. At Riou, for a few days in July the temperature exceeded $24^{\circ} \mathrm{C}$ down to a depth of $15 \mathrm{~m}$ (Figure 3 ), which lasted until the first wind in early August caused a strong upwelling. Symmetrically, a weaker but deeper hot event occurred at Medes (an area favourable for downwelling) in August down to a depth of $30 \mathrm{~m}$. Note that, most years (e.g. 2005), this kind of contrasted behaviour between Riou and Medes occurs more frequently due to regular Mistral and Tramontane winds. The Menorca site experienced two different heat events: one with temperatures reaching $27^{\circ} \mathrm{C}$ down to a depth of $10 \mathrm{~m}$ for a few days in July and one with temperatures between $24^{\circ} \mathrm{C}$ and $26{ }^{\circ} \mathrm{C}$ down to $30 \mathrm{~m}$ in August-September (Figure 3). In 2009, warming events were not as strong at Riou and Medes. At Scandola, an intense warming event occurred deeper and later with temperatures above $24{ }^{\circ} \mathrm{C}$ down to a depth of 20-25 m in August-September and temperatures reaching $27^{\circ} \mathrm{C}$ in late August. For a few days at Banyuls, the temperature reached $24^{\circ} \mathrm{C}$ in the first $10 \mathrm{~m}$ of the water column, which was not the case in other years. Unfortunately, no data were available for Menorca in 2009.

Two kinds of summer warming events thus emerged from this analysis of the temperature time series. Short very hot events with temperatures above $26{ }^{\circ} \mathrm{C}$ were restricted to the upper layers in 2006 and 2009 (Scandola, Menorca) (Figure 3). Warm events associated with temperatures above $23{ }^{\circ} \mathrm{C}$ lasted longer and affected deeper waters, i.e., down to a depth of 30 $\mathrm{m}$ in 2006 and 2009. Previous analyses of temperature anomalies in 1999 and 2003, which were responsible for large scale mass mortality events, also revealed two main types of positive thermal anomalies. The first type was characterized by short periods (2 to 5 days) with a high mean temperature reaching more than $27^{\circ} \mathrm{C}$, and a second type of anomaly which lasted nearly a month with warm temperatures $\left(23^{\circ} \mathrm{C}\right)$ (Crisci et al. 2011). 

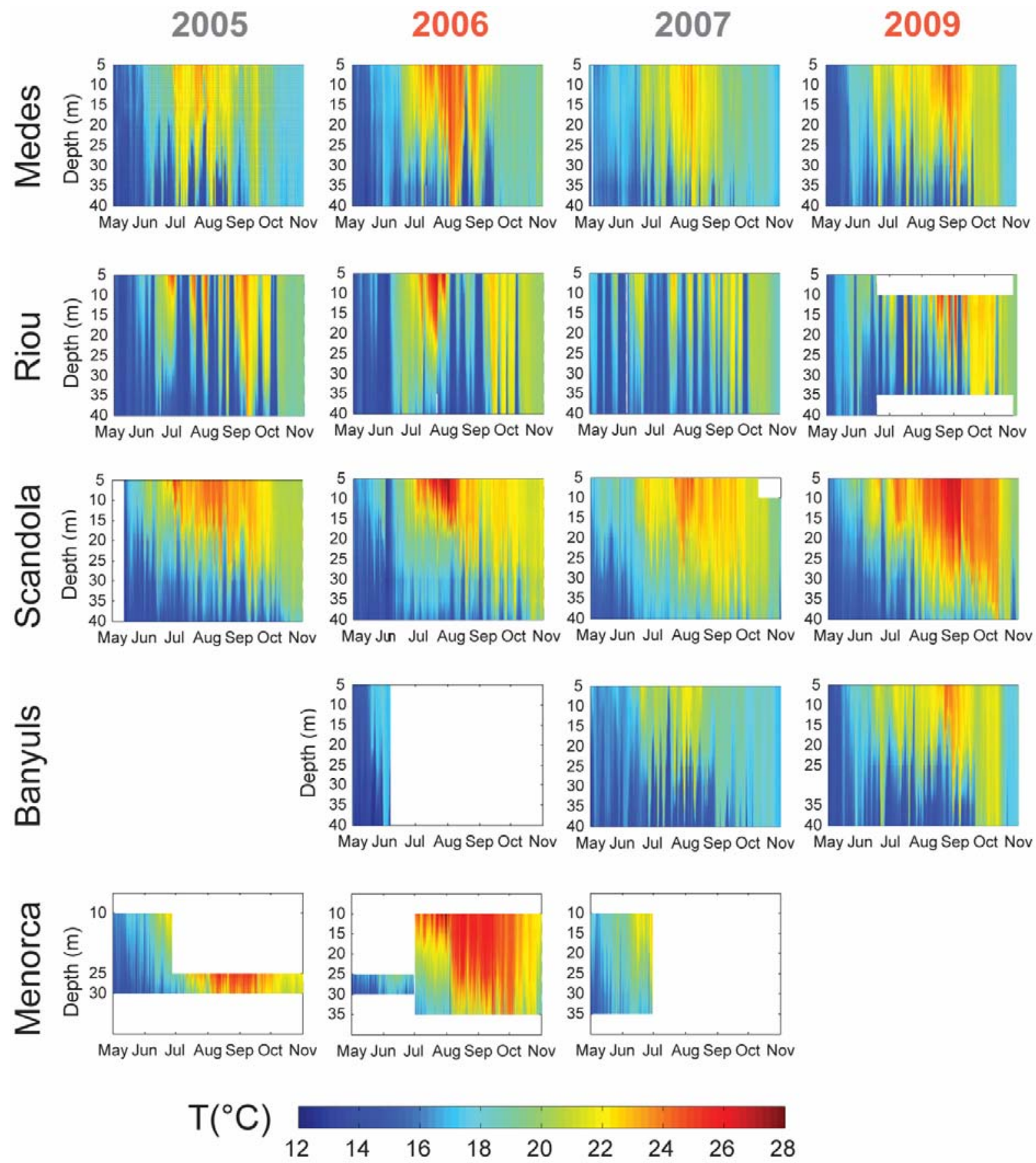

Figure 3

T-MedNet temperature time series for the summers in 2005-2007 and 2009 (May to October) at the Medes, Riou, Scandola, Banyuls and Menorca sites (see their locations in Figure 1 and Table 1). When missing, data were interpolated on the vertical for visualization purpose.

\subsubsection{Statistical validation of model temperature for the period 2001-2010}

To extrapolate the information provided by the in situ temperature monitoring to the entire NW Mediterranean coast, the coastal ocean model described in Section 2.1 was used to obtain summer temperature conditions for coastal areas. As explained in Section 2.2, the model was validated by comparing model statistics and T-MedNet observations over the period 20012010 (Table 2). 
A maximum bias was found in summer (Table 2), which showed more variability than winter over the study period. In agreement with a previous study (Pairaud et al. 2011), the model reproduced the temperature at the different locations close to the coast reasonably well, with a tendency to underestimate the temperature in subsurface layers. At a depth of $10 \mathrm{~m}$, the maximum monthly temperature bias in summer (averaged for the period 2001-2010) ranged from $-3{ }^{\circ} \mathrm{C}$ at Scandola in July-August (including strong warming events), to $0.7{ }^{\circ} \mathrm{C}$ at Banyuls, where the seasonal cycle tended to be smoothed by the model. The vertically and temporally averaged absolute bias during the stratified period was highest at Scandola (1.2 ${ }^{\circ} \mathrm{C}$ ), along with a maximum in the Root Mean Square (RMS) associated with the model's difficulties in simulating the strong temporal and vertical variability. The mean absolute bias (Table 2) was lowest at Medes $\left(0.3^{\circ} \mathrm{C}\right)$, where the vertical pattern and warming were more homogeneous. At Riou, the RMS was $1.6^{\circ} \mathrm{C}$, associated with strong summer variance. On the vertical (not shown here), the mean absolute bias was higher in deeper water than at the surface at the Medes, Banyuls and Menorca sites, whereas it was similar at Riou and lower at Scandola, where the model reproduced surface temperatures better than deeper temperatures.

The correlation coefficients (Table 2) confirm the model's ability to reproduce temporal variations in temperature during the stratified periods. The values were high, ranging from 0.8 to 0.9 on average. The minimum was observed at Riou, where the model underestimated summer temperature variability in the upper layers (up to $10^{\circ} \mathrm{C}$ in a few hours caused by heating or cooling). The correlation coefficients were found to be greater than 0.9 in the first $15 \mathrm{~m}$ of the water column at Medes, Banyuls and Scandola.

Including the previous results, the rank obtained from cumulative scoring of all descriptors gave the best match between modelled and observed data at Banyuls (Table 2), especially in subsurface layers, at a sensor resolution of $0.2^{\circ} \mathrm{C}$.

The modelled temperature thus generally compared well with observed values. As our focus was on our ability to reproduce the extreme hot summer temperature, the 10th upper percentile was computed (Table 2). The observed maximum 10\% upper temperatures over the period were above $20.5{ }^{\circ} \mathrm{C}$ at Banyuls, $23.9{ }^{\circ} \mathrm{C}$ at Scandola and $25.6{ }^{\circ} \mathrm{C}$ at Menorca. The upper layer temperatures were well reproduced at Banyuls, Medes and Menorca, where the model tended to estimate cooler temperatures than in situ recorded temperatures. The upper layer temperatures were underestimated by approximately $2{ }^{\circ} \mathrm{C}$ at Riou and Scandola.

\subsubsection{Inter-annual variability of model errors}

To assess the inter-annual variability of model errors, the time series of model temperature profiles were plotted for comparison with observations shown in Figure 3. The Hovmoller diagrams for Medes and Riou NORMED temperature and bias from the in situ data for the years 2006, 2007 and 2009 (Figure 4) exhibit well reproduced global temperature patterns at both sites for those years and intense warming events were identified in 2006.

At the Medes site (Figure 4), summer warming in July-August 2006 and 2009 was well reproduced by the model, but spread over greater depth (extreme heating was underestimated in the first $25 \mathrm{~m}$ of the water column and overestimated between $25 \mathrm{~m}$ and $40 \mathrm{~m}$ ). The local maximum observed temperature values were not reached by the model whatever the depth (difference of around $1^{\circ} \mathrm{C}$ ) (Figure 4, lower panel). The percentiles 90, which is equivalent to the minimum temperature of the warmest $10 \%$ of the temperature values, indicates that the model reproduced most of the temperature pattern in 2007 and in 2009 at depths below $10 \mathrm{~m}$ quite well, but not above a depth of $30 \mathrm{~m}$ in 2006. Analysis of previous years (data not shown) indicated that summer warming was too strong and too long close to the surface in 2002- 
2004, thus showing great inter-annual differences that were not taken into account when the statistics for the entire period 2001-2010 were analysed. Indeed, meteorological forcing changed (and improved) in 2005 and this had a strong influence on the modelled coastal temperature.

\begin{tabular}{|c|c|c|c|c|c|c|c|c|c|}
\hline \multicolumn{2}{|l|}{$\begin{array}{l}\text { Name of } \\
\text { site }\end{array}$} & \multicolumn{2}{|c|}{$\begin{array}{l}\text { Annual cycle at a depth of } 10 \mathrm{~m} \\
\text { (multi-annual monthly average) }\end{array}$} & \multicolumn{4}{|c|}{$\begin{array}{l}\text { Stratified period (1 May-30 October) } \\
\text { (vertically averaged statistics) }\end{array}$} & \multicolumn{2}{|c|}{$\begin{array}{l}\text { Stratified period (1 May-30 October) } \\
\text { (warm temperature at a depth of } 10 \mathrm{~m} \text { ) }\end{array}$} \\
\hline & & $\begin{array}{l}\text { Monthly bias } \\
\text { (winter) }\end{array}$ & $\begin{array}{l}\text { Monthly bias } \\
\text { (summer) }\end{array}$ & $\begin{array}{l}\text { Mean } \\
\text { bias } \\
\text { (abs.) }\end{array}$ & RMS & $\begin{array}{l}\text { Correlation } \\
\text { coefficient }\end{array}$ & Ranking & $\begin{array}{l}\text { 10th upper } \\
\text { percentile }\end{array}$ & $\begin{array}{l}\text { Bias on 10th } \\
\text { percentile }\end{array}$ \\
\hline \multirow{2}{*}{ Medes } & MOD & -0.1 & -0.52 & 0.3 & 1.3 & 0.84 & & & -0.4 \\
\hline & TMN & & & & & & & 21.7 & \\
\hline \multirow{2}{*}{ Riou } & MOD & -0.3 & -1.78 & 0.5 & 1.6 & 0.81 & & & -1.9 \\
\hline & TMN & & & & & & & 21.4 & \\
\hline \multirow{2}{*}{ Scandola } & MOD & 0.8 & -3.05 & 1.2 & 1.9 & 0.82 & & & -2.2 \\
\hline & TMN & & & & & & & 23.9 & \\
\hline \multirow{2}{*}{ Banyuls } & MOD & -0.6 & 0.66 & 0.5 & 1.0 & 0.89 & 1 & & 0.1 \\
\hline & TMN & & & & & & & 20.5 & \\
\hline \multirow{2}{*}{ Menorca } & MOD & -0.5 & -0.89 & 0.8 & 1.4 & 0.93 & & & $-0,7$ \\
\hline & TMN & & & & & & & 25.6 & \\
\hline
\end{tabular}

\section{Table 2}

Comparison of the NORMED simulated temperature (MOD) and the T-MedNet observed temperature (TMN) for 2001-2010 at the five sites listed in Table 1. The monthly bias at a depth of $10 \mathrm{~m}$ was calculated from the yearly average. The strongest monthly bias is shown for winter and summer respectively, with negative bias standing for a model underestimation. Vertically averaged statistics were computed for the stratified period between May and October by averaging the values at each depth. Absolute mean bias, root mean square and correlation coefficient are given. Ranking was obtained from cumulative scoring of all descriptors ( 1 indicates the best). In order to compare maximum temperature values during the stratified period, the 10th upper percentile of observed temperatures at a depth of $10 \mathrm{~m}$ are given together with the related model bias.

At the Riou site, the bias was found to be weak (less than + or $-1{ }^{\circ} \mathrm{C}$ ) and centred around zero for the mean bias (Figure 4). For 2006 and 2009, the bias was positive close to the surface and became negative (positive) below a depth of 25-30 m during warmer (cooler) events. Like for Medes, the model showed the same tendency to underestimate the maximum temperature, especially in the first 20-30 m of the water column. The bias for the maxima was less than $-1{ }^{\circ} \mathrm{C}$ at all depths for the period 2005-2010 (Figure 4, lower panel), which was two or three times smaller than for the period 2001-2004. The maximum temperature and the 10th upper percentile were underestimated. 

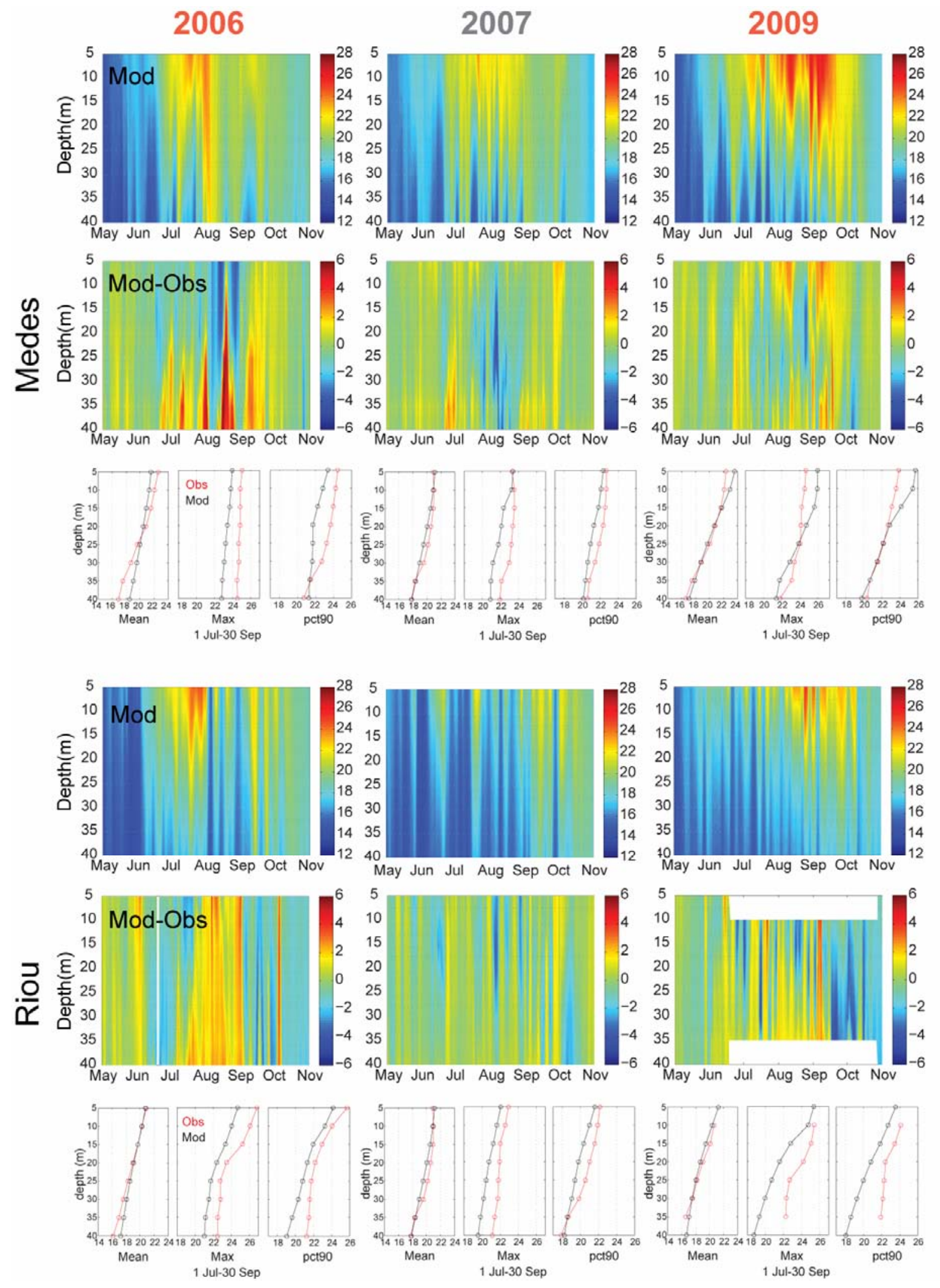

\section{Figure 4}

NORMED model temperature hindcast time series for the summers in 2006, 2007 and 2009 (May to October) at the Medes, Riou, Scandola, Banyuls and Menorca sites (upper panels). Bias from in situ time series of Figure 3 (lower panels), and statistics on the difference between the model and observations (mean bias, maximum and percentile90, temporally averaged over the July to September period). 
The model's underestimation of summer warming in the first few dozen metres of the water column also applied to the Menorca and Scandola sites, where the events reproduced by the model were too short in duration. This was particularly true for Scandola in 2006 between 10 and $30 \mathrm{~m}$ depth. Once more, Banyuls behaved differently, the length of the summer warming was well reproduced by the model, with a tendency to overestimate warming in deeper water, while mean values were very close to observed values.

To conclude, even if the model had a tendency to underestimate the extreme summer temperatures, the comparisons showed that the simulations were in good agreement with observed values, with better statistics for the period 2001-2010 for some regions (Catalonia, Banyuls, Marseille area) than for others (Corsica, Balearic Islands), especially during warming events. The model performed better during the second half of the ten year period, i.e., 2005-2010.

\subsection{Assessing the sensitivity of benthic communities to warming in the NW Mediterranean: the case of the red gorgonian dominated community}

The thermo-tolerance function for the red gorgonian Paramuricea clavata populations indicated that on average a short (9 days) exposure to a temperature of $25{ }^{\circ} \mathrm{C}$ was necessary to observe the first signs of necrosis (Table 3 ). The range of exposure before observing necrosis varied from a minimum of 1 day and a maximum of 21 days indicating large inter-population response to the same thermal stress (Table 3). Similar results were observed for temperatures below $25{ }^{\circ} \mathrm{C}$ (Table 3). However, for temperatures above $25{ }^{\circ} \mathrm{C}$, the population suffered from necrosis after only a few days of exposure, indicating that exposure to temperature $25{ }^{\circ} \mathrm{C}$ could be considered as critical for this species.

The inter-population differences observed in the response to thermal stress could be related to different adaptative processes (mainly acclimatation and local adaptation), as observed in other benthic species (Baums 2008). However, no relationship was evident with the geographic area and depth range of populations considered. Further research would be required (including genetic analysis) in order to reveal the factors explaining the observed differences (Crisci et al. 2011).

The compilation of data on the distribution of Paramuricea clavata allowed us to determine its presence in most of the sectors of the NW Mediterranean, except in those with a sandy bottom. More interestingly, the data compilation showed clear differences in the upper distribution level of populations varying from a depth of $10 \mathrm{~m}$ to $40 \mathrm{~m}$ depending on the area concerned. Although the factors behind these differences were not further investigated here, it appears that the upper distribution limit was deeper in warm areas than in cold ones. Similar differences were already documented in a study on the distribution of $P$. clavata along the NE coast of Spain (Linares et al. 2008). 


\begin{tabular}{llll} 
Temperature threshold $\left({ }^{\circ} \mathrm{C}\right)$ & \multicolumn{3}{l}{ No. of days before lethal effect } \\
\cline { 2 - 4 } & Min. & Mean & Max. \\
\hline 23 & 37 & 49 & 83 \\
24 & 21 & 22 & 22 \\
25 & 1 & 9 & 21 \\
26 & 3 & 4 & 5 \\
27 & 2 & 3 & 4 \\
28 & 2 & 2 & 2 \\
Associated risk level & Moderate & High & Extreme \\
\hline
\end{tabular}

\section{Table 3}

Summary of the thermo-tolerance functions compiled from field observations and thermo-tolerance experiments. The risk level is associated with the length of exposure at different temperatures before lethal effect.

\subsection{Maps of mass mortality risk}

As described in Section 2.4, we used the model temperature hindcasts combined with the thermo-tolerance and distribution information on the red gorgonian Paramuricea clavata to produce maps of mortality risk. The statistics on the model errors were used to correct the temperature hindcasts. According to our results (Figure 4 and Table 2), a mean estimated bias of $2.5{ }^{\circ} \mathrm{C}$ was added to the model temperature from Cote Bleue $\left(5^{\circ} \mathrm{E}, 43.3^{\circ} \mathrm{N}\right)$ to Monaco $\left(7.9^{\circ} \mathrm{E}, 43.8^{\circ} \mathrm{N}\right)$ and a mean estimated bias of $1^{\circ} \mathrm{C}$ was added to the rest of the domain except for the area extending from Medes to Banyuls.

The resulting maximum exposure (duration) to different temperature thresholds $\left(23{ }^{\circ} \mathrm{C}\right.$ to 28 ${ }^{\circ} \mathrm{C}$ ) was calculated from 2001 to 2010 for each model grid cell and vertical level. As an example, exposure to temperatures above $23{ }^{\circ} \mathrm{C}$ is shown in Figure 5a. Combining the modelled duration of exposure to the temperatures considered with the respective duration of the four levels of mortality risk (Table 3 in Section 3.2), we were able to qualify the mortality risk for each area and depth range (Figure $5 \mathrm{~b}$ ) in areas where P. clavata has been found (Figure 2). The maximum resulting risk was determined with regard to the temperature considered. For instance, if the duration of exposure at $23{ }^{\circ} \mathrm{C}$ corresponded to a high mortality risk and the exposure to other temperature thresholds corresponded to a moderate risk level, we only considered the high risk level obtained for $23{ }^{\circ} \mathrm{C}$. Finally, the risk of mortality for $P$. clavata populations was determined considering the mortality risk level attributed at the depth corresponding to the upper distribution limit of the populations for each area (Figure 5b, 6a and 6b).

Populations of the red gorgonian Paramuricea clavata in the upper $15 \mathrm{~m}$ were generally exposed to lethal temperature stress except in the cold Gulf of Lions area where P. clavata upper distribution limit is the shallowest: a depth of around $10 \mathrm{~m}$ (Figure 5b). It is interesting to note that the upper distribution of populations matched the distribution of moderate-high mortality risk obtained for the period 2001 to 2010 quite well (Figure 5b and Figure 6c). This could mean that populations did not colonize upper depth ranges because they could have suffered from temperature stress in the past, although other factors such as competition and 
food availability could also be involved in the observed distribution (Zabala et Ballesteros 1989; Coma et al. 2000).

a)

$12 \quad 3$

b)
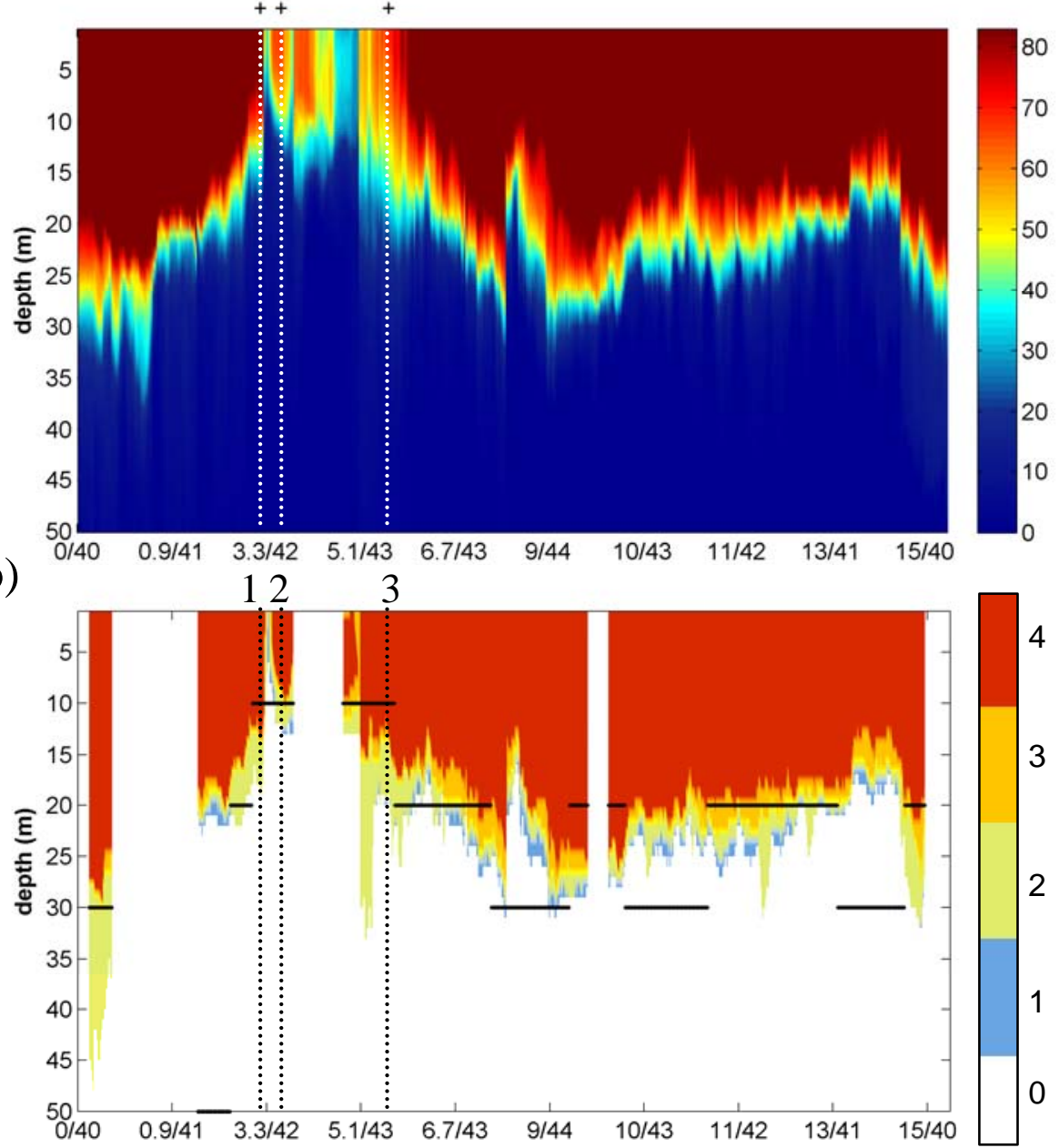

Figure 5

Map showing the temperature and locations of red gorgonian $P$. clavata under thermal stress in the continental band over the period 2001-2010. Location of Medes, Banyuls and Riou sites are numbered (1, 2, 3 respectively) and shown as dotted lines. a) Distribution of the number of days with temperatures above $23^{\circ} \mathrm{C}$ in summer (max. of years 2001-2010). b) Distribution of the impact level, from sub-lethal to medium, high, and extreme lethal impact (score 1 to 4 ) for coastal areas hosting $P$. clavata. The upper distribution limit of $P$. clavata is shown as black horizontal lines with a $10 \mathrm{~m}$ vertical resolution. 

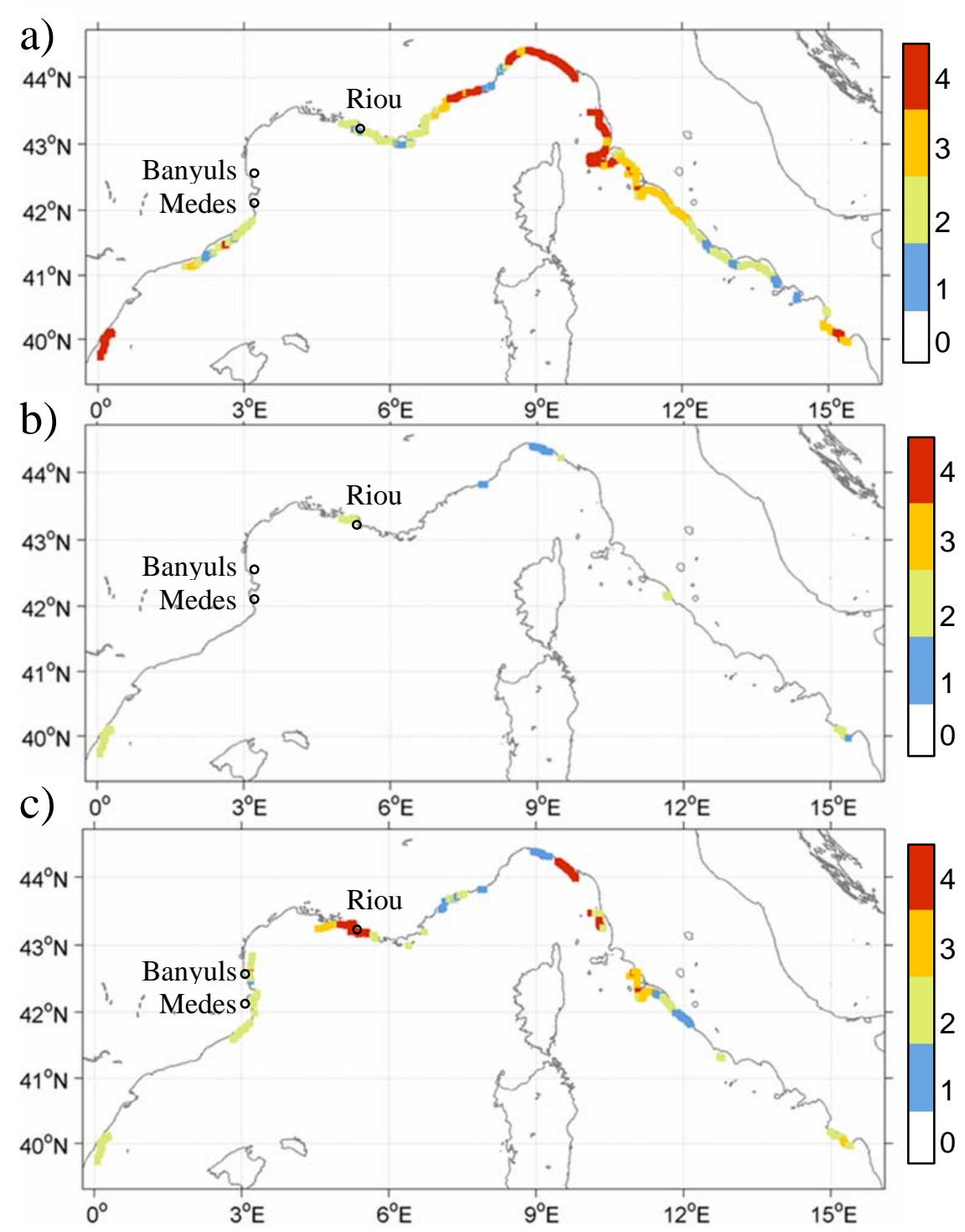

Figure 6

Map of risk for the red gorgonian $P$. clavata based on integrating the thermo-tolerance thresholds and species geographical and vertical distribution information and using model temperature hindcasts over the period 2001-2010. Map of potential thermal stress at a depth of $20 \mathrm{~m}$ (a) and of $30 \mathrm{~m}$ (b). c) Map of the impact of sub-lethal to extreme lethal temperature stress on $P$. clavata populations for the years 2001-2010 (scores between 0 and 4 with same colors as in Figure 5b).

Based on our results, the highest impacts were observed in the Marseilles area and in the Gulf of Genoa, while mortality risks were lower along the Catalan coast, especially in the northern part (Figure 6c). This pattern is in agreement with observations on population impacts conducted during the large mass mortality events in different areas of the north-western Mediterranean (Garrabou et al. 2009, Crisci et al. 2011). However, some of the areas which suffered severe impacts during the 2003 mass mortality events were not well represented (Garrabou et al. 2009). For instance, the risk level in the area of Port Cros $\left(6.5^{\circ} \mathrm{E}, 43^{\circ} \mathrm{N}\right)$ was underestimated in both magnitude and in horizontal extension. This suggests that areas with a low density of model points should also be interpreted as being exposed to mortality risk. Also, the relatively deep $P$. clavata populations in the area of Napoli were strongly affected in 2003 (Garrabou et al. 2009) but the risk estimated by the model was only high in subsurface 
layers, suggesting a major bias. Unfortunately, no temperature data series were available to evaluate the model error in this area.

Overall, the lethal thermal stress conditions rarely reached a depth of $30 \mathrm{~m}$ in the model (Figure 6Figure 6b), suggesting that only shallow populations were exposed to thermal stress. However, this is not in agreement with observations of deeper populations which have been locally affected in the past decade at sub-regional scale after the 1999 summer due to intense but short-lived warming events down to 40 to $50 \mathrm{~m}$ in depth (Cerrano et al. 2000; Perez et al. 2000). Thus the mortality risk should be extended to deeper areas by improving the model's representation of deeper extreme temperature. The narrow range $\left(1^{\circ} \mathrm{C}\right.$ to $2{ }^{\circ} \mathrm{C}$ and a few days of exposure) between favourable and potentially lethal conditions and the quality of the data should be better taken into account in the model ratings. Errors in the model temperature hindcasts at the different sites have to be better integrated to correct the scores in cases in which the intensity or duration of summer temperature extremes were not well reproduced by the NORMED model. This is particularly critical at intermediate depths given the range of upper distribution limits of the populations and the strong vertical gradients in this depth range (Figure 6a and $b$ ).

\section{Conclusion}

In this paper, we propose a method to model the current mass mortality risk associated with thermal stress of benthic coastal ecosystems at the scale of the NW Mediterranean, using the red gorgonian Paramuricea clavata as a model species. The risk levels in the different NW Mediterranean areas showed fairly good agreement with observed mass mortality impacts, with a higher risk level in the Marseilles and Genoa areas than along the Catalan coast. The results of this study thus validate our methodological approach.

However, several improvements need to be made in the process of mapping the risk of mortality. First, the modelled temperature conditions should take better into account the model ratings, especially in areas where the intensity or duration of summer temperature extremes were not well reproduced by the model. This is a key issue because the observed mass mortality events were concomitant with warm to extreme temperature conditions. Of course biological and ecological factors (e.g. food supply, genetic factors) can modulate the response of populations, which would explain the differential degree of mortality as observed at inter- and intraspecific level during the main reported mortality events (1999 and 2003) (Cerrano et al. 2000; Garrabou et al. 2009). However, our goal here was to model the occurrence of mortality events rather than their severity.

On the other hand, thermo-tolerance functions should be improved to better assess the mortality risks. It seems urgent to include information of a larger number of populations and species in order to provide a more global view of the risks at the community level. In the future it would be worth including the potential effects of adaptive processes (e.g. identifying areas less resistant to thermal stress) and studying how environmental conditions (e.g. food supply) can modulate the response of organisms to thermal stress.

In the framework of this study, the next step will be to assess the impacts of climate change on mass mortality events by the end of the $21^{\text {st }}$ century in the NW Mediterranean. We will apply the method developed here using the climatic IPCC scenarios of Somot et al. (2006, 2008) to identify which zones are the most sensitive to climate change.

In this paper, we considered one species affected by mass mortality as one example of the potential biological impacts of temperature anomalies. The same methodology could be 
applied to explore impacts of other processes associated with climate change such as the migration of species, shifts in reproductive cycles, jelly fish blooms and the survival of larvae. Overall, this approach will provide a more comprehensive view on the expected impacts.

Finally, our study provides information at appropriate spatial scales to guide the development of sound management and conservation strategies to mitigate the impacts of climate change on the rich marine biodiversity in the Mediterranean Sea and the socio-economic services linked to coastal ecosystems.

\section{Acknowledgments}

This work was supported by the CLIMCARES project funded by the TOTAL foundation (http://climcares.medrecover.org). We thank the Pytheas Observation Service, the Reserve Naturelle Marine de Cerbere-Banyuls, the Reserve Naturelle de Scandola, the Parc Natural del Montgrí, Illes Medes i Baxi Ter for providing the temperature records and information on the red gorgonian distribution. The mortality risk assessment could not be possible without the collaboration of MPA managers and scientists that kindly answer our questionnaire on the distribution of gorgonian: Silvia Cocito (ENEA), Carlo Cerrano (Polytechnic University of Marche), Giovanni Santangelo (Univesity of Pisa), Luisa Mangialajo (ECOMERS), Stéphane Sartoretto (IFREMER) and managers from Aire Marine Protégée des Posidonies du Cap d'Agde and Parc Marin de la Côte Bleue. Finally we are thankful to Cristina Linares, Emma Cebrian, Núria Teixidó, Jean-Baptsite Ledoux, Silvija Kipson, members of the Marine Conservation Research Group MedRecover 2009-SGR-1174 (www.medrecover.org), for the use of demographic data of the red gorgonian populations. This study was also part of the 'Mistrals MERMEX WP2-ICOCE' and international 'IMBER', 'SOLAS' and 'LOICZ' projects.

\section{References}

Andre G, Garreau P, Garnier V, Fraunié P (2005). Modelled variability of the sea surface circulation in the north-western Mediterranean Sea and in the Gulf of Lions. Ocean Dyn 55: 294-308

Andre G, Garreau P, Fraunié P (2009). Mesoscale slope current variability in the Gulf of Lions. Interpretation of in situ measurements using a three-dimensional model. Cont Shelf Res 29: 407-423

Bally M, Garrabou J (2007). Thermodependent bacterial pathogens and mass mortalities in temperate benthic communities: a new case of emerging disease linked to climate change. Glob Change Biol 13: 2078-2088

Baums I (2008). A restoration genetics guide for coral reef conservation. Molecular Ecology $17: 2796-2811$

Bensoussan N, Romano JC, Harmelin JG, Pascual J, Garrabou J (2009). Warming trends, regional fingerprints and future trajectories of NW Mediterranean coastal waters. Proceedings of the first Mediterranean symposium on coralligenous and other calcareous bio concretions, Tabarka, 15-16 January 2009, Tunisia, pp 167-168

Bensoussan N, Romano JC, Harmelin JG, Garrabou J (2010). High resolution characterization of northwest Mediterranean coastal waters thermal regimes: to better understand responses of benthic communities to climate change. Estuar Coast Shelf S 87:431-441 
Calvo E, Simó R , Coma R, Ribes M, Pascual J, Sabatés A, Gili JM, Pelejero C (2011).

Effects of climate change on Mediterranean marine ecosystems: the case of the Catalan Sea.

Clim Res 50:1-29

Cebrian E, Uriz MJ, Garrabou J, Ballesteros E (2011). Sponge mass mortalities in a warming Mediterranean Sea: are Cyanobacteria-Harboring species worse off? PLoS ONE 6(6): e20211. doi:10.1371/journal.pone.0020211

Cerrano C, Bavestrello G, Bianchi CN, et al. (2000). A catastrophic mass-mortality episode of gorgonians and other organisms in the Ligurian Sea (north-western Mediterranean), summer 1999. Ecol Lett 3: 284-293

Coll M, Piroddi C, Steenbeek J, Kaschner K, Ben Rais Lasram F, et al. (2010). The biodiversity of the Mediterranean Sea: estimates, patterns, and threats. PLoS ONE 5: e11842

Coma R, Ribes M, Gili JM, Zabala M (2000) Seasonality in coastal benthic ecosystems.

Trends in Ecology \& Evolution, 15(11):448-453

Coma R, Ribes M, Serrano E, Jiménez E, Salat J, Pascual J (2009). Global warming-enhanced stratification and mass mortality events in the Mediterranean. Proc. Natl. Acad. Sci. USA 106:6176-6181

Crisci C, Bensoussan N, Romano JC, Garrabou J (2011). Temperature anomalies and mortality events in marine communities: insights on factors behind differential mortality impacts in the NW Mediterranean. PLoS ONE 6(9): e23814. doi:10.1371/journal.pone.0023814

Crisci C (2011) Détermination des risques pour la conservation des populations d'espèces longévives de Méditerranée nord-occidentale dans le contexte du changement climatique. Dissertation, Université de la Méditerranée.

Déqué $M$ (2007). Frequency of precipitation and temperature extremes over France in an anthropogenic scenario: model results and statistical correction according to observed values. Global Planet Change 57: 16-26

Doney SC, Ruckelshaus M, Duffy JE, Barry JP, et al. (2012). Climate change impacts on marine ecosystems. Annu Rev Mar Sci 4:11-37

Dufois F, Garreau P, Le Hir P, Forget P (2008). Wave and current-induced bottom shear stress distribution in the Gulf of Lions. Cont Shelf Res 28, 1920-1934.

Garrabou J, Coma R, Bensoussan N., Bally M, et al. (2009). Mass mortality in northwestern Mediterranean rocky benthic communities : effects of the 2003 heat wave. Global Change Biol 15:1090-1103

Giorgi F, Lionello P (2008). Climate change projections for the Mediterranean region. Global Planet Change 63: 90-104 
Grell GA, Dudhia J, Stauffer DR (1994). A Description of the Fifth-Generation Penn State/NCAR Mesoscale Model (MM5). NCAR Tech. Note NCAR/TN 398STR

Harley CDG, Randall Hughes A, Hultgren KM, Miner BG, Sorte CJB, et al. (2006). The impacts of climate change in coastal marine systems. Ecol Lett 9: 228-241

Harvell CD, Kim K, Burkholder JM, Colwell RR, Epstein PR, et al. (1999). Emerging marine diseases. Climate links and anthropogenic factors. Science 285: 1505-1510

IPCC 2007 (2007). Climate Change 2007: The Physical Science Basis, Contribution of Working Group I to the Fourth Assessment Report of the IPCC, Cambridge University Press, Cambridge.

http://www.ipcc.ch/publications_and_data/publications_ipcc_fourth_assessment_report_wg1_ report_the_physical_science_basis.htm

Kipson S (2013). Community and population ecology analysis of gorgonian dominated communities in the Adriatic sea. Dissertation, University of Zagreb

Lazure P, Dumas F (2008). An external-internal mode coupling for a 3D hydrodynamical model for applications at regional scale (MARS). Adv Water Resour 31: 233- 250

Levitus S, Antonov J, Boyer TP, Stephens C (2000). Warming of the world ocean. Science 287:2225-2229

Linares C, Coma R, Garrabou J, Diaz D, Zabala M, (2008). Size distribution, density and disturbance in two Mediterranean gorgonians: Paramuricea clavata and Eunicella singularis. J Appl Ecol 45: 688-699

Millot C (1979). Wind induced upwellings in the Gulf of Lions. Oceanol Acta 2: 262-274

Millot C (1990). The Gulf of Lions' hydrodynamics. Cont Shelf Res 10 (9-11): 885-894

Nicolle A, Garreau P, Liorzou B (2009). Modelling for anchovy recruitment studies in the Gulf of Lions (Western Mediterranean Sea). Ocean Dyn 59:953-968

Pairaud I, Gatti J, Bensoussan N, Verney R, Garreau P (2011). Hydrology and circulation in a coastal area off Marseille: validation of a nested 3D model with observations. J Marine Syst 88:20-33

Pérez T, Garrabou J, Sartoretto S, Harmelin JG, Francour P, Vacelet J (2000). Mortalités massives d'invertébrés marins: un évènement sans précédent en Méditerranée nordoccidentale. C R Acad Sc Paris Biol 323: 853-865

Perry AL, Low PJ, Ellis JR, Reynolds JD (2005). Climate change and distribution shifts in marine fishes. Science 308:1912-1915

Previati M, Scinto A, Cerrano C, Osinga R (2010). Oxygen consumption in Mediterranean octocorals under different temperatures. J Exp Mar Biol Ecol 390: 39-48 
Rubio A, Taillandier V, Garreau P (2009). Reconstruction of the Mediterranean northern current variability and associated cross-shelf transport in the Gulf of Lions from satellitetracked drifters and model outputs. J Mar Syst 78:63-78

Russell B, Connell S (2012). Origins and consequences of global and local stressors: incorporating climatic and non-climatic phenomena that buffer or accelerate ecological change. Mar Biol 159:2633-2639

Schaeffer A, Garreau P, Molcard A, Fraunie P, Seity Y (2011). Influence of high-resolution wind forcing on hydrodynamic modeling of the Gulf of Lions. Ocean Dyn 61(11):1823-1844

Somot S, Sevault F, Déqué M (2006). Transient climate change scenario simulation of the Mediterranean Sea for the twenty-first century using a high resolution ocean circulation model. Clim Dyn 27:851-879

Somot S, Sevault F, Déqué M, Crépon M (2008). 21st century climate change scenario for the Mediterranean using a coupled atmosphere-ocean regional climate model. Global Planet Change 63: 112-126

Trenberth K (2012). Framing the way to relate climate extremes to climate change. Climatic Change 115:283-290

Wernberg T, Smale DA, Tuya F, Thomsen MS, Langlois TJ, De Bettignies T, Bennett S, Rousseaux CS (2013). An extreme climatic event alters marine ecosystem structure in a global biodiversity hotspot. Nature Clim Change 3:78-82

Wernberg T, Russell B, Thomsen M, Gurgel C, Bradshaw C, Poloczanska E, Connell S (2011). Seaweed Communities in Retreat from Ocean Warming. Curr Biol 21:1828-1832

Zabala M, Ballesteros E (1989). Surface-dependent strategies and energy flux in benthic marine communities or, why corals do not exist in the Mediterranean. Sci Mar 53(1): 3-17 